\title{
Lip and Oral Cavity Cancer TNM Finding v6
}

National Cancer Institute

\section{Source}

National Cancer Institute. Lip and Oral Cavity Cancer TNM Finding v6. NCI Thesaurus. Code C64391.

A finding about one or more characteristics of lip and oral cavity cancer, following the rules of the TNM AJCC v6 classification system. 